\title{
Organizational Culture and Voluntary Disclosure Practices of Listed Firms in Nigeria
}

\author{
Samson I. Nyahas ${ }^{1}$, Joseph M. Ntayi², Nixon Kamukama ${ }^{3} \&$ John C. Munene ${ }^{2}$ \\ ${ }^{1}$ Department of Accounting, University of Jos, Nigeria \\ ${ }^{2}$ Makerere University Business School Kampala Uganda \\ ${ }^{3}$ Mbarara University of Science and Technology, Uganda \\ Correspondence: Samson I. Nyahas, Department of Accounting University of Jos, Nigeria. Tel: 234-8062-793- \\ 119. E-mail: talk2nyahas@gmail.com
}

Received: March 24, 2018; Accepted: April 13, 2018; Published: May 6, 2018

\begin{abstract}
The purpose of this paper is to test the relationship between organizational culture and voluntary disclosure by listed firms in Nigeria. The research design for the study is survey design that is cross-sectional nature to examine the relationship among the study variables. Data for organizational culture were obtained from administration of questionnaire while that for voluntary disclosure were from financial reports of 92 listed companies. To test our main hypotheses, we used Structural Equation Model (SEM) especially PLS-SEM. The results indicate that both ritualism and opportunism dimensions of organizational culture are positively associated with voluntary disclosure. This implies that, firms' emphasis on rules as well as flexibility in response to changing environmental needs promote the practice of voluntary disclosure in annual reports. This study concludes that voluntary disclosure is associated with flexibility in policies and disclosure rules as well as strict adherence to laylaid down guideline for the identification and measurement of disclosure items.
\end{abstract}

Keywords: voluntary disclosure, ritualism, opportunism, and developing country, Nigeria

\section{Introduction}

\subsection{Introduction to the Problem}

This study reports the contribution of two organizational culture variables (ritualism and opportunism) to variation in voluntary disclosure practice in Nigeria. Voluntary disclosure complements mandatory disclosure as key component of corporate governance principles (Nyahas, Munene, Orobia \& Kaawaaseh, 2017; Qu \& Leung, 2006). Voluntary disclosure is the release of information by companies in excess of the minimum mandatory requirements of regulatory bodies (Boesso \& Kumar, 2007). Voluntary disclosure provides stakeholders with information that helps them understand whether current earnings are sustainable; working of the capital markets thereby boosting Foreign Direct Investments (FDIs) (Qu, Leung, Wise \& Cooper, 2013; Qu \& Leung, 2006).

In the context of developing countries like Nigeria, disclosure practices by publicly listed companies are adjudged to be weak and inadequate over time (Damagum \& Chima, 2013; World Bank, 2011; 2004). This is evident in the fact that some firms present financial reports, which are considered by some stakeholders as incomplete and inaccurate (Sanusi, 2010). This has the potential to deprive investors of the right information to make the right decision. This development if not checked may erode investor's confidence in the Nigerian capital market leading to reduction in FDIs to the country. This underscores the need to promote voluntary disclosure practice by companies in Nigeria.

Empirically, studies have associated voluntary disclosure with such factors as firm size, age, leverage, profitability and asset quality (Bhatia \& Tuli, 2017; Ziba \& Asadi, 2016; Soliman, 2013, 2011, Lan, Wang \& Zhang, 2012; Barako, 2007). Others focus on corporate governance elements like ownership structure, board size, board structure, auditor type and board independence (Damagum \& Chima, 2013; Kurawa \& Kabara, 2014); Akhtaruddin \& Rouf, 2012; Barako, 2007; Eng \& Mak, 2003). Though these studies have expanded our understanding of factors associated with voluntary disclosure, they seem to ignore the fact that corporate disclosure is a management activity which is driven by a set of acceptable norms within an organization (Gibbins, Richardson \& Waterhouse, 1990). The concept of organizational culture provides an avenue to study how firms manage disclosure issues within the firm (Nyahas et al., 2017). This study differs from previous empirical studies because 
we examined the association between organizational cultural practices that influence and voluntary disclosure. Though prior scholars have examined the association between organizational culture and voluntary disclosure, such studies are very few.

Contextually, scholars in Nigeria have examined factors associated with voluntary disclosure practice of listed firms (Uchenna \& Bwala, 2013; Damagum \& Chima, 2013; Adelopo, 2011). These studies however, focused on firm characteristics such as firm's size, board size, profitability and leverage with no focus on internal practices such as organizational culture. Additionally, there is documentary evidence to suggest that organizational culture influences voluntary disclosure practices of firms in the United Arab Emirate (see Elkelish \& Hassan, 2014. In the Nigeria context, such evidence seems to be elusive in the disclosure literature. This study, therefore, seeks to contribute to knowledge by empirically examine the relationship between organizational culture and voluntary disclosure. The study also extents the debate on the effect of culture on corporate disclosure to organizational level rather than looking at national culture as it is the case with most prior studies in this area (see Akhtaruddin \& Rouf, 2012; Qu \& Leung, 2006; Hannifa \& Cooke, 2002; Gray, 1988).

The focus of this study is on Nigeria for a number of reasons. First Nigeria is one of the largest economies in Africa besides South Africa and Egypt. According to Euler Hermes Economic Research Reports (2017), the country has the dominant economy in the West Africa sub-region and one of the continent's largest economies as at 2015. The country has a total population of 178.51 million and a GDP of 568.51 as at the same time period. However, one of the weaknesses of the Nigerian economy is over-reliance on the export of crude oil which accounts for over $90 \%$ of export revenue making the economy susceptible to volatility in global energy prices (Euler, 2017). Therefore, the need to promote other sectors of the Nigerian economy besides oil and gas sector is a pressing one. But the challenge is that the country has a long history of economic mismanagement and corruption, which has affected the perception of doing business in the country Euler, 2017).

Moreover, the large number of listed firms in Nigeria relative to other countries in the sub-Sahara Africa provides another motivation for the choice of the country. The rest of the paper is structured as follows: Next section looks at the literature review and hypothesis development, then the methodology, results, discussion and conclusion.

\section{Literature Review and Hypotheses Development}

\subsection{Voluntary Disclosure}

Voluntary disclosure has been described as the issue of company information through any channel of communication (Gibbins, Richardson \& Waterhouse, 1990). It is also seen as deliberate choice of which information to be released on the part of a company's management to provide information believed to be important to the decision needs of stakeholders (Qu, Leung \& Cooper, 2013). The Financial Accounting Standards Board looks at voluntary disclosure as the release of information, which is principally outside the requirements of company law or expressly required by accounting standards (FASB, 2001). In this study, therefore, voluntary disclosure is considered as any information in annual reports, which is principally outside the requirements of International Financial Reporting Standards (IFRSs) or required by the Nigerian Company and Allied Matters Act (1990), which is the legal document guiding corporate disclosure in Nigeria in line with FASB definition. We therefore, consider, disclosure requirements of the Nigerian Code of corporate governance as voluntary since SEC made compliance by firms voluntary (comply or explain. Consequently, corporate disclosure in such areas as management projection, environmental impact assessment, stakeholders as well as ethical matters are considered voluntary.

Prior empirical studies have examined the relationship between national culture and corporate disclosure (Once \& Almagtome, 2014; Akhtaruddin \& Rouf, 2012; Gallen \& Peraita, 2017; Gray, 1988; Qu \& Leung, 2006; Hannifa \& Cooke, 2002;). Such approach does not provide sufficient understanding at the specific organizational level (see Elkelish \& Hassan, 2014; Hofstede, Neuijen, Ohayv \& Sander, 1990). This study differs from other studies in the sense that it examines the effect of culture at the organizational level.

\subsection{Organizational Culture}

The word culture connotes a set of standards for gauging what constitute an acceptable behaviour within a society or group. Hostede (1984) define culture as the collective programing of the minds, which distinguishes one group from another. He identified five dimensions of national culture that influence accounting practices around the globe. These dimensions include individualism versus collectivism; strong versus weak uncertainty avoidance, masculinity versus feministic, large versus small power distance, long versus short-term orientation.

Prior studies have shown that national culture has proven to be an important factor influencing the extent of disclosures by companies (Herath \& Carlis, 2017). In examining the influence of culture on voluntary disclosure, 
earlier scholars rely on either Hostestede (1984) or Gray (1988) cultural model. For example, Zaman, Monir and Rahaman (2009) using Gray's cultural model to study differences in voluntary disclosure between Indian and New Zealand companies. They documented that there is a strong link between country culture and voluntary disclosure. Similarly, Qu and Leung (2006) examined the effect of cultural change on the voluntary disclosure practices of Listed firms in China. Their result indicates that there was an increase in the degree of information voluntarily disclosed by the firms. Once and Almagtome (2014) also investigated the effect of national culture values on voluntary disclosure of environmental information in Turkey using the Hosfstede (1984) national culture values. Their findings indicate that individualism and long-term orientation are related to environmental disclosures.

At the organizational level, scholars such as Schein (1995) and Hofstede et al. (1990) provide the theoretical basis to explain organizational culture. Schein (1995) for example define, organizational culture as ...." a pattern of basic assumptions that a given group has invented, discovered, or developed in learning to cope with its problem of external adaptation, and that have worked well enough to be considered acceptable, and therefore, to be taught to new members as the way to perceive, think, and feel in relation to their problems". This definition is inline with Hofstede et al. (1990) who defined organizational culture "as a collective mental programming found among people in different organizations or parts thereof, within the same national culture". Similarly, Elkelish and Hassan (2014) defined organizational culture as "....shared perception of organizational work practices within organizational units that may differ from other organizational units".

We view organizational culture in terms of flexibility or strict adherence to company' disclosure norms for the recognition and measurement of items not required by accounting standards and company law. This is in line with Gibbins, Richardson and Waterhouse (1990) who suggest that managers have tendency towards strict adherence to disclosure norms and rules (ritualism) or seek specific advantage for the measurement and disclosure of information (opportunism) especially when such disclosure items are voluntary.

\subsection{Hypotheses Development}

Empirically, studies examining the link between organizational culture and voluntary disclosure are scarce. One of such studies is that conducted by Elkelish and Hassan (2014) who investigated the association between organizational culture and voluntary risk disclosure by listed firms in the United Arab Emirate using Cameron and Quinn (1999) model. Their result indicates that organizational culture of clan which focus on formalized work procedures is associated with voluntary risk disclosure. Similarly, Sejjaakaa, (2004) states that high level of formalization is achieved through existence of lay down policies and procedures. Unfortunately, previous theoretical and empirical literature does not provide a clear indication of the relationship between organizational culture and voluntary disclosure (Elkelish \& Hassan, 2014). To address this concern, Gibbins et al (1990) presented a model for predicting corporate disclosure whether mandatory or voluntary.

An essential role of Gibbins et al.'s (1990) model to the disclosure literature is that it projects organizational culture, as internal antecedence influencing firms' disclosure output. In the model, the authors argued that firm's strategic response to any disclosure issue is predicated on internal antecedence such as the way information is managed. According to them, the firms' traditional ways of doing things may establish how disclosure is managed: in terms of either disclosure is perceived as a ritual or provides an opportunity to seek firm' specific advantage for the disclosure of the specific item especially if such is voluntary. This study adopts the Gibbins et al (1990) disclosure model to examine the relationship between organizational culture and voluntary disclosures because we believe that these two attributes (ritualism and opportunism) are mutually exclusive and reasonably comprehensive.

Ritualistic culture focuses on strict control thereby laying much emphasis on stability, predictability, efficiency and procedures, which are considered essential within an organizational culture (Hofstede, Neuijen, Ohayv \& Sanders, 1990). This is achieved through a well-formalized and structured workplace (Cameron \& Quinn, 1999). Formalized work procedures are achieved through hierarchical organizational structure where the emphasis is on adherence to rules, policies and procedures (Adams, 1997; Sejjaakaa, 2005). With ritualistic culture, managers play a rather passive role in the management of corporate disclosure since there exist rules and procedures to be followed in the identification measurement and disclosure of corporate information (Gibbins et al, 1990; Adams, 1997) even if such is voluntary in nature. Formalized work procedure is synonymous to ritualistic culture that explains the tendency for organizational members to adhere strictly to lay down disclosure norms, rules and procedure (Adams, 1997; Gibbins et al, 1990). Empirical evidence suggests that there is a connection between ritualistic culture and voluntary disclosure (see Eklelish \& Hassan, 2014; Sejjaakaa, 2004). In this study, it is believe that firms listed on the stock exchange have well lay down policies and reporting procedures that guide disclosure of corporate information. We therefore hypothesize thus: 
$\mathrm{H}_{1}$ : Ritualistic organizational culture will be positively related to voluntary disclosure practice of listed firms in Nigeria.

Another cultural practices affecting firms' disclosure output identified by Gibbins et al (1990) is opportunism. This is described as firm's tendency to seek specific advantage in the disclosure of information. This is influenced by external antecedents such as corporate politics, target market, competition and which stakeholder group matter for in the disclosure decision particularly when such is voluntary in nature (Adams, 1997). Here the focus is on results rather than efficiency, rules and precision (Cameron \& Quinn, 1999). This suggests that in an opportunistic culture, managers' attitude towards disclosure may reflect the belief or action of those with responsibility for disclosure. The concept of opportunism suggests that managers take an active stance in the disclosure process. This means that under opportunistic culture the focus of management is on cost-benefit analysis to determine if disclosure of information is to the benefit of the firm or not especially when such is voluntary. This is enhanced through a flexible organizational structure characterized by high concentration of authority, less formalizations of work procedures, and more tolerance for ambiguity (Elkelish \& Hassan, 2014; Hosfstede, 2001). In this type of organizational culture, departments or individual managers have high discretion over disclosure decision. Gibbins et al. (1990) argue that the degree to which sub-units are given discretion over disclosure decisions will determine the extent to which the entities voluntarily disclose information in annual reports. Drawing from the Gibbins et al. (1990) model and empirical evidence (Adams, 1990) we hypothesize thus

$\mathrm{H}_{2}$ : There is a positive relationship between opportunistic culture and voluntary disclosure practice by listed firms in Nigeria

\section{Methodology and Variable Measurement}

\subsection{Research Design}

The study adopted a survey design. The population included of all the 192 publicly listed companies participating in the Nigerian Stock Exchange. A sample size of 129 firms was considered adequate (Krejcie \& Morgan 1970). Due to the heterogeneous nature of the population, stratified random sampling was found suitable for the study following Blumberg, Schindler and Cooper (2014). As such, the population was stratified according to Securities and Exchange industrial classification. Firms in the same industry were randomly selected for the purpose of questionnaire administration. At the end of the field survey, we received a total 92 valid responses from the participating firms.

\subsection{Sample Characteristics}

In this study, it was essential to understand the demographic characteristics of the respondents and background information of the firms. Gender distribution showed a fair spread between males and females with $53.3 \%$ males and $46.7 \%$ are females. This indicates listed firms in Nigeria are gender sensitive in their recruitment policy. Most respondents (30.8\%) are accountants, 27.2\% are internal auditors, and 25\% are public relation officers while $29.2 \%$ are marketing officers and others. We also looked at professional qualification. The statistic indicates that the accounting professional accountants dominate with $49.2 \%$. This is an indication that most of the respondents have adequate knowledge of the subject matter under investigation. The frequency distribution indicate that majority of those who responded to the survey questionnaire $58.5 \%$ have either a bachelor's degree or its equivalent (higher national diploma). This implies that most of those who responded to he questionnaire have the ability to read and understand the questions and provide an appropriate response

Since the unit of analysis for this study is at companies' level, it is essential that we consider the characteristics of the participating companies. In this regard, we considered industrial category and firm's age (measured as years of operations on the Nigerian market). In terms of industrial category, the financial sector dominates with (32.6\%). This is a reflection of the fact that the Nigerian capital market is dominated by the financial sector. We also considered the length of time the participating firms have been operating in the Nigerian capital market. The statistics showed that $57.6 \%$ of the firms have been participating for a period ranging between 21-40 years. Suggesting that most of the firms visited during the data collection have sufficient knowledge of the Nigerian capital market.

\subsection{Measurement of Variables}

Voluntary Disclosure: This variable was operationalized as any release of information that is not specifically required by IFRSs or Companies and Allied matters Act, 1990) laws of the Federal Republic of Nigeria. As such, information in such areas as management's strategic forecast, environment, and relationship with stakeholders and ethical issues were considered voluntary for the purpose of the study. Consistent with prior studies on voluntary disclosure, the study employed the index approach to measure the extent disclosure (Akhtaruddin \& Rouf, 2012; 
Boesso \& Kumar, 2009; Eng \& Mak, 2003). We prepared a disclosure checklist comprising of strategic and forward looking information, environmental, and social information. We prepared the checklist to enable us select items of information in annual reports that are not mandatorily required by Nigeria Companies and Allied Matters Act 2004, or International Financial Reporting Standards. The disclosure checklist for this study covers 25 items in areas of; strategic, environmental, social and ethical information in line with Damagum and Chima (2013) see appendix 1.

The question in previous studies is whether to score disclosure items based on weighted or un-weighted method. It has been argued that the weighted approach may introduce a bias towards a particular user orientation, while the un-weighted approach dwells on the belief that all items are uniformly important (Barako, et al., 2006). In order to avoid bias we used the un-weighted approach. Each item was scored (1) if disclosed in the annual reports and (0) if otherwise in line with Akhtaruddin and Rouf (2012). The disclosure index adopted for the study is in line with earlier studies (Akhtaruddin \& Rouf 2012):

$$
\text { Dscore }=\sum \mathrm{n}^{\mathrm{dj}}
$$

$\mathrm{i}=1$

Where:

Dscore $=$ the aggregate disclosure score.

$\mathrm{dj}=1$ if the $\mathrm{jth}$ item is disclosed or 0 if not disclosed

$\mathrm{n}=$ the maximum score each company can obtain.

Ritualism: was operationalized to measure the degree of control and formalization of work procedures. As such we measure the extend to which managers adhere to policies, rules and procedures for identification and disclosure of corporate information. This study adopted and modified questionnaires employed by earlier scholars (Sejjaakaa, 2005) to measure the extent to which managers agree to statements such as "there is a formal way of doing things in this organization that employees should follow;" "There is a hierarchy of information flow that must be observed in this organization"; Employees are required to obey company procedures laid down by board of directors. We employed a five point Likert scale ranging from 1. (Strongly disagree) to 5. (Strongly agree).

Opportunism: was operationalized to as the degree to which firms seek specific advantage in the disclosure of corporate information if such disclosure is at their discretion. The scales were adopted and modified from those developed by prior studies Gibbins (1990); (Sejjaakaa, 2004; Adams, 1997). Some of the items on the scale include; Employees are encouraged to experiment new ways of doing things; There is less formalization of reporting procedures in this organization; we change our disclosure policies to meet up with contemporary environmental challenges. These statements were placed on a 5-point Likert scale ranging from 1. (Strongly disagree) to 5. (Strongly agree).

Control variables: the study controlled for the effect of board size and industry category as these have been found in previous studies to have influence on voluntary disclosure (Albawwat, 2015; Ziba, 201). In Nigeria, listed firms are not permitted to have board members less than five as contained in the Nigerian Code of Corporate Governance 2008. This variable was measured the sum total of all the directors on the board of a firm in line with previous studies (Albawwat, 2015). Industry category was measured as a dichotomous variable of 1 if the firm operates in the financial sector or 0 if otherwise.

\section{Data Analysis and Results}

We employed the use of Structural Equation Model (SEM) with the aid of Partial Least Squares (PLS), specifically SmartPLS3. In this study, the sample size is <200 therefore PLS was found suitable (Henseler \& Sarstedt, 2013). The reliability and validity were examined using the measurement model while the study hypotheses were tested using the structural model as suggested by Henseler, Hubona and Ray (2016).

\subsection{Validity and Reliability}

Since the dependent and control variables were modelled as uni-dimensional constructs, hence do not need to be evaluated for reliability and validity (Mashahadi, Ahmad \& Mohamad, 2016). Therefore the independent variables (ritualistic culture and opportunistic culture) were assessed for validity and reliability.

Construct validity was tested in two dimensions of convergent and discriminant validity.

Convergent validity: Here the focus is on the Average Variance Extracted (AVE). For convergent validity to be established the AVEs for all the constructs should be 0.5 and above (Hair et al., 2010). The result in table 1 
indicates that the AVEs for both ritualism and opportunism meet the minimum threshold indicating they measure the same latent variable.

Table 1 . Measurement model indicating reliability

\begin{tabular}{llllll}
\hline Organizational culture & $\begin{array}{l}\text { Item } \\
\text { loadings }\end{array}$ & $\begin{array}{l}\text { Cronbach } \\
\text { Alpha }\end{array}$ & $\begin{array}{l}\text { Composite } \\
\text { reliability }\end{array}$ & AVE & VIF \\
\hline Ritualism & & $\mathbf{0 . 7 8 8}$ & $\mathbf{0 . 8 6 1}$ & $\mathbf{0 . 6 0 9}$ & $\mathbf{1 . 3 5 7}$ \\
\hline $\begin{array}{l}\text { There is a formal way of doing things in this } \\
\text { organization that employees must follow }\end{array}$ & 0.741 & & & & \\
$\begin{array}{l}\text { There is a hierarchy of information flow that must } \\
\text { be observed in this organization }\end{array}$ & 0.847 & & & & \\
We follow written documents on company & 0.661 & & & \\
procedures when disclosing information not \\
required by IFRSs
\end{tabular}

Discriminant validity: To establish discriminant validity, the Fornell and Larcker (1981) criteria were used as recommended by Latan (2015). The criteria suggest that the square root of Average Variance Extracted (AVE) in each latent variable can be examined to establish discriminant validity. The results show that the square root of the AVE for each variables is more than correlation values among the other latent variables. This confirms that items measuring different variables were indeed seen to be measuring the same underlying constructs. Thus discriminant validity is established see table 2 (square root of AVEs in parenthesis)

Table 2. Discriminant validity

\begin{tabular}{llllll}
\hline & Board size & $\begin{array}{l}\text { Industry } \\
\text { category }\end{array}$ & $\begin{array}{l}\text { Ritualisti } \\
\text { c culture }\end{array}$ & $\begin{array}{l}\text { Voluntary } \\
\text { disclosure }\end{array}$ & Opportunism \\
\hline Board size & 1 & & & & \\
$\begin{array}{l}\text { Industry category } \\
\text { Ritualism }\end{array}$ & 0.003 & $\mathbf{1}$ & & & \\
& 0.069 & 0.080 & $\mathbf{( 0 . 7 8 1 )}$ & & \\
Voluntary disclosure & 0.111 & 0.006 & 0.651 & $\mathbf{1}$ & \\
Opportunism & 0.135 & 0.174 & 0.513 & 0.550 & $\mathbf{( 0 . 8 5 9 )}$ \\
\hline
\end{tabular}

Reliability: In this study, we focused on composite reliability" as a measure of internal consistency instead of Cronbach's alpha since Cronbach's Alpha tends to provide a conservative measurement in PLS-SEM (Wong, 2013). To establish internal consistency, scholars suggest that composite reliability should be 0.7 and above (Hair et al., 2010). From the measurement model in table 2, all variables meet up the minimum threshold 0.7 and above signifying high internal consistency of the measurement tool.

For the dependent variable (voluntary disclosure) we use the inter-coder reliability test in line with prior studies on (Sejjaakaa (2005). This was carried out using the Cohen's kappa coefficient to establish the reliability of the disclosure index. The researchers and two neutral persons scored 20 randomly selected annual reports to track and 
code voluntary disclosure items using the checklist developed by the researchers. The scores of the independent coders were compared with the researcher's score and found to have a Pearson product moment of the correlation coefficient of $=0.883 \mathrm{p} \leq$ value $<0.05$ indicating high reliability of the indext (Boesso \& Kumar, 2007; Sejjaaka, 2005).

\subsection{Test of Hypotheses}

In testing the hypotheses we assessed the structural model. Table 3 and appendix 3 indicate that the independent variables account for $49.8 \%$ variation in the behaviour of the dependent variable $\left(R^{2}=0.498\right)$. To test the hypothesized paths, we examination of the path coefficients. The results indicate that ritualism was significant in explaining variation involuntary disclosure $(\beta=0.500, \mathrm{t}=6.838 \mathrm{p} \leq 0.05)$ thus hypothesis $\mathrm{H}_{1}$ was supported.

Opportunism was also found significantly related to voluntary disclosure $(\beta=0.306, \mathrm{t}=3.910, \mathrm{p}>0.05)$, thus hypothesis $\mathrm{H}_{2}$ was supported. The control variable Board size and industry category are not associated with voluntary disclosure with $(\beta=-0.034, t=0.086, p>0.05)$ and $(\beta=-0.098, t=0.060, p>0.05)$ respectively.

The effect size was assessed by examining the $\left(\mathrm{f}^{2}\right)$ as suggested by Henseler and Sarstedt (2013). The effect size was examined based on Hair et al (2013) who describes the criteria for evaluation of the size effect. Based on their criteria, $\mathrm{f}^{2}$ values of $0.02,0.15$ and 0.35 respectively indicate small, medium and strong effects on the endogenous variable. The effect size of ritualism and opportunism on voluntary disclosure is considered strong $\left(\mathrm{f}^{2}=0.366\right)$ confirming a strong relationship between the study variables (Latan, 2015). The effect size of opportunism is medium $\left(\mathrm{f}^{2}=0.132\right)$ indicating a weak relationship with the endogenous variable. The results are presented in table 3.

Table 3. Summary of structural model

\begin{tabular}{lllll}
\hline Variable & B & t-statistics & $\mathbf{f}^{\mathbf{2}}$ \\
\cline { 2 - 4 } & Ritualism & 0.500 & 6.838 & 0.366 \\
Opportunism & 0.306 & 3.910 & 0.135 \\
Industry category & -0.098 & 0.0603 & 0.019 \\
Board size & -0.034 & 0.086 & 0.002 \\
\hline
\end{tabular}

$R^{2}=0.498$, Adjusted $R^{2}=0.475$

\section{Discussion}

The result of testing hypothesis $\mathbf{H}_{\mathbf{1}}$ indicates that ritualism and voluntary disclosure are positively and significantly related. This suggests that strict adherence to organizational norms; disclosure policies and strategies encourage the practice of the voluntary disclosure. Such adherence to disclosure norms is made possible with hierarchical organizational structure, as is the case with publicly listed firms. These firms ensure that responsibilities for the measurement and disclosure of information are assigned to different parties within the firm. As such even if disclosure requirements change, routinized procedures can be established to ensure that every item is disclosed based on standard rule already established.

The finding is also in agreement with Elkelish and Hassan (2014) who documented that, hierarchical reporting structure is associated with voluntary disclosure of corporate risk. Similarly, Sejjaakaa (2005) documented that tight control over management of disclosures is associated with corporate disclosures. The findings further provide evidence that ritualism being the domain of organizational culture is a good predictor of voluntary disclosure. This validates Gibbins' et al. (1990) theoretical model of corporate disclosure, which assumes that uncritical adherence to disclosure norms, is associated with corporate disclosure. The result of testing hypothesis $\mathbf{H}_{2}$ established that opportunism and voluntary disclosure are associated. This suggests that flexibility in organizational culture helps firms to disclose more information in annual reports to meet the changing needs of various stakeholders. The finding, is in line earlier empirical findings. For example, Adams (1997) suggests that opportunism is associated with voluntary disclosure practices.

This study therefore concludes that listed firms in Nigeria are structured in such a way that gives them control over the way in which managers handle many organizational activities including voluntary disclosure. They also exhibit a level of flexibility, which helps them respond to the changing information needs of various stakeholders. As such the organizational culture can be said to be a blend between rigidity (ritualism) and flexibility (opportunism).

The study explored Gibbins et al. (1990) model to explain cultural influences on voluntary disclosure practices. The study finds support for both ritualism and opportunism as predictors of corporate disclosure. Suggesting that, 
studies in corporate disclosure utilizing organizational culture constructs should pay attention to the potential influence of specific cultural attributes such as management emphasis on strict adherence to lay down disclosure norms. This will further provide an empirical support to validate Gibbins et al. theoretical model for corporate disclosure (1990) model.

The study employed the use of both questionnaire and disclosure checklist to collect data for independent and the dependent variable respectively. This suggests that studies in accounting disclosure can utilize both primary and secondary data rather than relying solely on content analysis of annual reports as it is the case with most studies in this area.

One of the limitations of the study is its focus on firms on the stock exchange. The result may not reflect the behaviour of private firms. The use of survey questionnaire to measure perception of managers is subject to selfreporting bias. However, this was overcome by measuring the dependent variable using data from companies' annual reports. Also, another limitation of the study is small sample size relative to number of variables in the study.

\section{References}

Adams, M. (1997). Ritualism, Opportunism and Corporate Disclosure in the New Zealand life Insurance Industry: Field Evidence. Accounting, Auditing \& Accountability Journal, 10(5), 718-734 https://doi.org/10.1108/09513579710367962

Adelopo, I. (2011). Voluntary Disclosure Practices among listed firms in Nigeria. Journal of Advances in Accounting Incorporating Advances in International Accounting, 27, 338-345.

Akhtaruddin, M., \& Rouf, M. A. (2012). Corporate Governance, Cultural Factors and Voluntary Disclosure: Evidence from selected Companies in Bangladesh. Journal of Corporate Boards: Roles, Duties and composition, 8(1). Retrieved from http://www.fasb.org

Akhtaruddin, M., Hossain, M. A., Hossain, M., \& Yao, L. (2009). Corporate Governance and Voluntary Disclosure in Corporate Annual Reports of Malaysian Listed Firms. Journal of Applied Management and Accounting Research, 7(1), 1-19.

Albawwat, A., \& Ali-basah, M. Y. (2015). Corporate Governance and Voluntary of Interim Financial Reporting in Jordan. Journal of Public Administration and Governance, 5(2), 2161-7104. https://doi.org/10.5296/jpag.v5i2.7580

Alfraih, M. M., \& Almuwata, A. M. (2017). Voluntary Disclosure and Corporate Governance. Empirical evidence from Kuwait. International Journal of Law and Management, 59(2), 217-236. https://doi.org/10.1108/IJLMA-10-2015-0052

Amran, A., \& Haniffa, R. (2011). Evidence in Development of Sustainability Reporting: A case of Developing Country. Journal of Business Strategy and the Environment, 20, 141-156. Retrieved from http://www.wileyonlinelibrary.com

Bagozzi, R. P., \& Yi, Y. (1988). On the Evaluation of Structural Equation Models. Journal of the Academy of Marketing Science, 16(1), 74-94.

Barako, D. G. (2007). Determinants of Voluntary Disclosure in Kenyan Companies Annual Reports. African Journal of Business Management, 1(5), 113- 128.

Barako, D. G., Hancock, P., \& Izan, H. (2006). Relationship between Corporate Governance and Voluntary Disclosure in Annual Reports: The Kenyan experience. Journal of Financial Reporting and Governance, 5(1).

Bartov, E., Gul, R. A., \& Tsui, J. S. (2000). Discretionary-accruals Models and Audit Qualifications. Journal of Accounting and Economics, 30, 421-452.

Bhatia, A., \& Tuli, S. (2017). Corporate Attributes Affecting Sustainability Reporting: an Indian perspective. International Journal of Law and Management, 59(3). https://doi.org/10.1108/IJLMA-11-2015-0057

Binh, T. Q (2012). Voluntary Disclosure Information in the Annual Reports of Non-listed Companies: The Case of Vietnam. Journal of Applied Economics and Business Research, 2(2), 69-90.

Blumberg, B. F., Cooper, D. R., \& Schindler, S. P. (2014). Business Research Methods $4^{\text {th }}$ Edition. Published by McGraw- Hill Education (UK) Limited, New York, 2014.

Boesso, G., \& Kumar, K. (2007). Drivers of Corporate Voluntary Disclosure: A Framework and Empirical Evidence from Italy and the United States. Accounting, Auditing and Accountability Journal, 20(2), 269-296. 
Boesso, G., \& Kumar, K. (2009). An Investigation of Stakeholder Prioritization and Engagement: Who and Who Really Counts? Journal of Accounting and Organizational Change, 5(1), 62-80. https://doi.org/10.1108/18325910910932214

Cameron, K., \& Quinn, R. (1999). Diagnosing and changing organizational culture, Prentice Hall, NJ.

Damagum, Y. M., \& Chima, E. (2013). The Impact of Corporate Governance on Voluntary Information Disclosures of Quoted Firms in Nigeria: An Empirical Analysis. Research Journal of Finance and Accounting, 4(13), 2247.

Dincer, B. (2011). Do the Shareholders Really Care about Corporate Social Responsibility? International Journal of Business and Social Science, 2(10).

Elkelish, W. W., \& Hassan, M. K. (2014). Organizational culture and corporate risk disclosure. An empirical investigation for United Arab Emirate listed companies. International Journal of Commerce and Management, 24(4), 279-299

Eng, L. L., \& Mak, Y. T. (2003). Corporate Governance and Financial Disclosure. Journal of Accounting and Public Policy, 22(4), 325-345.

FASB. (2001). Improving Business Reporting: Insights into Enhancing Voluntary Disclosures. Steering Committee Reports, Business reporting research project. Retrieved from http://www.fasb.org

Field, A. (2009). Discovering Statistics Using SPSS third edition. SAGE Publications.

Financial Reporting Council (FRC) of Nigeria Act, (2011). Official Gazette No.54, June 2011 Vol. 98 Notice 140. Printed and Published by The Federal Government Printer Lagos, Nigeria.

Fornell, C., \& Larcker, D. F. (1981). Evaluating structural equation models with unobservable variables and measurement error. Journal of Marketing Research, 18(1), 39-50.

Gallen, M. L., \& Peraita, C. (2017). The Effects of National Culture on Corporate Social Responsibility disclosures: a cross country comparism. Journal of Applied Economics.

Gibbins, M., Richardson, A., \& Waterhouse, J. (1990). The management of Corporate Financial Disclosure; Opportunism, Ritualism, Policies and Processes. Journal of Accounting Research, 28(1), 121-143.

Gray, S. J. (1988). Towards a Theory of Cultural Influence on the Development of Accounting Systems. ABACUS, 1988.

Hair, J. F., Black, W. C., Babin, B. J., \& Anderson, R. E. (2010). Multivariate Data Analysis, seventh ed. Prentice Hall, Englewood Cliffs.

Hair, J. F., Hult, G. T. M., Ringle, C. M., \& Sarstedt, M. (2013). A Primer on Partial Least Squares Structural Equation modeling (PLS-SEM). Sage, Thousand Oaks.

Hanifa, R. M., \& Cooke, T. E. (2002). Culture, Corporate Governance and Disclosure in.

Henseler, J., Hubona, G., \& Ray, P. A. (2016). Using PLS path modeling in new tecnology research: Updated guidelines. Journal of Management and Data Systems, 116(1), 2-20. http://dx.doi.org/10.1108/IMDS-092015-0382

Henseler. J., \& Sarstedt, M. (2013). Goodness-of-fit indices for Partial Least Squares Path Modelling. Computational Statistics, 28(2), 565-580.

Herath, S., \& Carlis, E. (2017). Organizational culture and national culture and direct effects on accounting standards and procedures: A literature Review. The Business Management Review, 8(4).

Hofstede, G. (1980). Culture's Consequences: International Differences in Work-Related Values. Beverly Hills, CA: Sage.

Hofstede, G. (2011). Dimensionalizing Cultures: The Hofstede Model in Context. Online Readings in Psychology and Culture, 2(1). http://dx.doi.org/10.9707/2307-0919.1014

Hofstede, G., Neuijen, B., Ohayv, D. D., \& Sanders, G. (1990). Measuring Organizational Culture. A Qualitative Study Across Twenty cases. Administrative Science Quarterly, 35(2), 286-316. Retrieved from http://www.jstor.org/stable/2393392

Krejcie, R. V., \& Morgan, D. W. (1970). Determining Sample Size for Research Activities. Educational and Psychological Measurement.

Kurawa, J. M., \& Kabara, A. S. (2014). Impact of Corporate Governance on Voluntary Disclosure in the Down 
Stream Sector of The Nigerian petroleum Industry. Proceeding of World Business Research Conference April, 2014 Novotel World Trade center Dubai, ISBN 978-1-922069-48-1

Lan, Y., Wang, L., \& Zhang, X. (2013). Determinants and features of voluntary disclosure in Chinese stock market. China Journal of Accounting Research, 6, 265-285.

Latan, H. (2015). The results of partial least squares structural modelling analysis (PLS- SEM). Retrieved from https://www.researchgate.net/publication/272304948

Marquis, C., Toffel, M. W., \& Zhou, Y. (2015). Scrutiny, Norms and selective Disclosure: A global study of Green washing. Harvard Business School. A working paper july 13, 2015.

Mashahadi, F., Ahmad, N. H., \& Mohamad, O. (2016). Strategic Innovation Ambidexterity and Internationalization Performance of Small and Medium Enterprises: An insight into herbal based small and medium enterprises. World Journal of Entrepreneurship Management and Sustainable Development, 12(2), 161-175.

Molleda, J., Connolly-Ahew, C., \& Quinn, C. (2006). Cross National Conflict Shifting: Expanding a Theory of Global Public Relations Management Through Qualitative Content Analysis. Journal of Journalism Studies, $6(1)$.

Ntim, C. G., \& Soobaroyen, T. (2013). Black Economic Empowerment Disclosures by South African Listed Corporations: The Influence of Ownership and Board Characteristics. Journal of Business Ethics, 116(1), 121-138.

Nyahas, S. I., Munene, J. C., Orobia, L., \& Kigongo, K. T. (2017). Isomorphic influences and voluntary disclosure: The mediating role of organizational culture. Cogent Business \& Management, 4(1), 135-144.

Oliveira, L., Rodrigues, L. L., \& Craig, R. (2013). Stakeholder Theory and voluntary disclosure of intellectual capital in formation. Caspian Journal of Applied Sciences Research, 2(3), 75-93. Retrieved from http://www.cjasr.com ISSN: 2251-9114.

Omar, N., Johari, Z. A., \& Hasna, S. (2015). Corporate Culture and the Occurrence of financial Statement fraud. A Review of Literature. Procedia Economics, 31(3), 367-372.

Once, S and Almagtome, A. (2014). The Relationship between National Culture Values and Corporate Environmental Disclosures. An International Perspective. Research Journal of Business and Management, 11(3), 2148-6689.

Organization for the Economic Cooperation and Development (OECD). (2003). Best Business Practices for corporate social responsibility conference: Operational Conclusion. Brussels.

Pallant, J. (2007). SPSS Survival Manual: A step by step Guide to data Analysis using SPSS for windows. Third Edition. McGraw Open University press.

Podsakoff, P. M., Mackenzie, S. B., Podsakoff, N. P., \& Lee, J. (2003). Common Method Bias in Behavioral Research: A critical Review of the literature and Recommended Remedies. Journal of Applied Psychology, 88(5), 879-903.

Qu, W, Cooper, B, Wise, V., \& Leung, P. (2013). Voluntary Disclosure in a Changing Regulatory Environment: Evidence from Chinese Stock Market. Intertnational Journal of Economics and Finance, 4(4). Retrieved from http://www.ccsenet.org/ijef

Qu, W., \& Leung, P. (2006). Cultural impact on Chinese Corporate Disclosure - a Corporate Governance Perspective. Managerial Auditing Journal, 21(3), 241-264. http://dx.doi.org/10.1108/02686900610652991

Sanusi, L. S. (2010). The Nigerian Banking Industry: What Went Wrong and the Way Forward. A paper presented at the Bayero University to mark the annual convocation ceremony of the University on the 26 February, 2010.

Schein, E. H. (1995). Organizational culture and leadership. $3^{\text {rd }}$ edition

Schuster, P., \& O'Connell, V. (2006). The Trend towards Voluntary Corporate Disclosure. Journal of management Accounting quarterly, 7(2).

SEC (2008). Code of Corporate Governance for listed Companies in Nigeria. Retrieved from http://www.sec.gov.ng

Sejaaka, S. (2004). A process base model for corporate mandatory disclosure. Working paper Makerere University Business School Uganda. 
Sejjaaka, S. K. (2005). Corporate Mandatory Disclosure Practice by Financial Institutions in Uganda. Unpublished thesis submitted to Makerere University Business School in partial fulfillment for the award of the degree of doctor of philosophy $(\mathrm{PhD})$ degree of Makerere University.

Soliman, M. M. (2013). Firm Characteristics and the Extent of Voluntary Disclosure. The case of Egypt. Research Journal of Finance and Accounting, 4(17), 2222-2847. Retrieved from http://www.iiste.org

The Nigerian Code of Corporate Governance. (2011). A publication of The Nigerian Securities and Exchange Commission. Retrieved from http://www2.deloitte.com/ng/en/pages/centre-

Wong, K. K. (2013. Partial Least Squares Structural Modeling PLS-SEM Techniques using SmartPLS. Marketing Bulletin 2013, 24 technical note 1.

World Bank. (2004). Report on the Observance of Codes (ROSC) Nigerian Accounting and Auditing. June 17, 2004.

World Bank. (2011). Report on the Observance of Codes (ROSC) Nigerian Accounting and Auditing. June 6, 2011.

Ziba, E., \& Asadi, A. (2016). The study of Relationship between Corporate Characteristics and Voluntary Disclosure in Tehran stock exchange. International Journal of Business Management, 10(7), 117-127.

\section{Appendix 1. Disclosure Checklist}

\begin{tabular}{ll}
\hline \multicolumn{2}{c}{ Strategic information } \\
\hline 1 & Company's mission statement \\
2 & Brief history of the company \\
3 & Organizational structure/chart \\
4 & Description of major goods/services produced \\
5 & Likely effect of business strategy on current performance \\
6 & Review of current financial results and discussion of major factors underlying performance \\
7 & Educational qualification/Academic level of Board of Directors \\
8 & Information about directors Remuneration \\
9 & Information on Attendance and frequency of Board meetings \\
10 & Share Capitalization history \\
\hline
\end{tabular}

\begin{tabular}{ll}
\hline \multicolumn{2}{c}{ Forward-looking information } \\
\hline 11 & Factors that may affect future performance \\
12 & Director's projection of future performance \\
13 & Planned research and development \\
14 & Information relating to the general outlook of the economy and its likely impact on future \\
& performance \\
15 & Disclosure relating to competition in the industry and its impact on future performance \\
\hline
\end{tabular}

\begin{tabular}{ll}
\hline Social and ethical Disclosure \\
\hline 16 & Disclosure of policy on corruption \\
17 & Statement on actual cases of corruption were handled during the year \\
18 & Statement on its relationship with the host community \\
19 & Statement on company relationship with key stakeholders \\
20 & Relationship with customers \\
\hline \multicolumn{2}{l}{ Environmental } \\
\hline 21 & Statement of environmental policy \\
22 & Information about employee workplace safety \\
23 & Social responsibility \\
24 & Statement about environmental risk management \\
25 & Overview of how business operations impact on the environment \\
& Overall score \\
\hline
\end{tabular}




\begin{tabular}{lllll}
\hline 1 & 2 & 3 & 4 & 5 \\
\hline $1-20 \%$ & $21-40 \%$ & $41-60 \%$ & $61-80 \%$ & $81-100 \%$ \\
\hline
\end{tabular}

Adapted and modified from Damagum and Chima (2013) Akhtaruddin and Rouf (2012).

\section{Appendix 2. Questionnaire}

\section{A Survey Questionnaire}

\section{Section 1}

Introduction:

The objective of this study is to investigate association between organizational culture and voluntary corporate disclosure practices by Nigerian listed firms. Your responses shall be used strictly for academic purpose only. To maintain high level of confidentiality, your name or that of your firm is not required.

Thank you for your cooperation

General guide:

Before you begin, please read the following guidelines below:

a) When evaluating the questions, please provide responses from your own perspective, as honestly as possible.

b) You are requested to apply the scale provided for each of the questions.

c) Please note that your name is not required nor is it requested, hence confidentiality is assured.

I would like to express my utmost gratitude for your participation!

Thank you.

\section{Section 2}

\section{Company Background}

\section{Please tick as appropriate}

1. What industrial sector does your organization belong? Financial [ 1 ] Manufacturing [ ] Agriculture [ ] Mining [ ] Petroleum[]

2. Average size of employees in your organization: 1-50 [ ] 51-100 [ ] 101-150 [ ] 151-200 [ ] 201 \&above [ ]

3. How many branches does your firm has? 1-5 [ ] 6- 10 [ ] 11-15 [ ] 16-20 [ ] 21 \& above [ ]

\section{Section 3}

Personal Background of Respondent

\section{Personal and Education Data}

1. Please indicate your age group

\begin{tabular}{ll}
\hline $20-25$ & 1 \\
$26-35$ & 2 \\
$36-45$ & 3 \\
\hline $46-$ Above & 4 \\
\hline
\end{tabular}

2. What is your gender?

\begin{tabular}{ll}
\hline Male & 1 \\
\hline Female & 2 \\
\hline
\end{tabular}

3. What position do you hold in this organization? Manager [ ] Accountant [ ] Internal auditor [ ] Public Relations manager [ ], others please specify.

4. What is your educational qualification PhD [ ] Masters [ ] $1^{\text {st }}$ degree/HND [ ] Diploma/NCE [ ] WAEC/WASC [] 
5. Professional qualification if any ICBN [ ] ICAN/ ANAN/ACCA [ ] Marketing [ ] ICPRN [ ] others please specify.

\section{Organizational Culture:}

\section{Ritualism}

Instructions: Please indicate to what extent you agree with the following statements

\begin{tabular}{|c|c|c|c|c|c|c|}
\hline & Statement & $\begin{array}{l}\text { Strongly } \\
\text { Disagree }\end{array}$ & Disagree & $\begin{array}{l}\text { Moderately } \\
\text { Agree }\end{array}$ & Agree & $\begin{array}{l}\text { Strongly } \\
\text { Agree }\end{array}$ \\
\hline RA1 & $\begin{array}{l}\text { There is a formal way of doing things in } \\
\text { this organization that employees must } \\
\text { follow }\end{array}$ & 1 & 2 & 3 & 4 & 5 \\
\hline RA2 & $\begin{array}{l}\text { New employees are required to go } \\
\text { through formal induction training } \\
\text { before they are given work schedules }\end{array}$ & 1 & 2 & 3 & 4 & 5 \\
\hline RA3 & $\begin{array}{l}\text { There is a hierarchy of information flow } \\
\text { that must be observed in this } \\
\text { organization }\end{array}$ & 1 & 2 & 3 & 4 & 5 \\
\hline RA4 & $\begin{array}{l}\text { This firm has history of reporting } \\
\text { information on the environment }\end{array}$ & 1 & 2 & 3 & 4 & 5 \\
\hline RA5 & $\begin{array}{l}\text { We have a standard for gauging what } \\
\text { constitute unethical behaviour in this } \\
\text { organization }\end{array}$ & 1 & 2 & 3 & 4 & 5 \\
\hline RA6 & $\begin{array}{l}\text { Employee are required to follow } \\
\text { company procedures laid down by } \\
\text { board of directors without questioning } \\
\text { the logic }\end{array}$ & 1 & 2 & 3 & 4 & 5 \\
\hline RA7 & $\begin{array}{l}\text { Our disclosure procedures in this } \\
\text { company tend to be repetitive }\end{array}$ & 1 & 2 & 3 & 4 & 5 \\
\hline
\end{tabular}

\section{Opportunism}

\begin{tabular}{|c|c|c|c|c|c|c|}
\hline & Statement & $\begin{array}{l}\text { Strongly } \\
\text { Disagree }\end{array}$ & Disagree & $\begin{array}{l}\text { Moderately } \\
\text { Agree }\end{array}$ & Agree & $\begin{array}{l}\text { Strongly } \\
\text { Agree }\end{array}$ \\
\hline OP1 & $\begin{array}{l}\text { Employees are encouraged to } \\
\text { experiment new ways of doing things }\end{array}$ & 1 & 2 & 3 & 4 & 5 \\
\hline OP2 & $\begin{array}{l}\text { When reporting to my superior, there is } \\
\text { a more emphasis on results than } \\
\text { procedures }\end{array}$ & 1 & 2 & 3 & 4 & 5 \\
\hline OP3 & $\begin{array}{l}\text { Managers at all levels have autonomy to } \\
\text { make certain decisions on behalf of the } \\
\text { company }\end{array}$ & 1 & 2 & 3 & 4 & 5 \\
\hline OP4 & $\begin{array}{l}\text { Our organizational policy is open to } \\
\text { change to meet up with current } \\
\text { environmental challenges }\end{array}$ & 1 & 2 & 3 & 4 & 5 \\
\hline OP5 & $\begin{array}{l}\text { We evaluate cost/benefit of disclosure } \\
\text { before disclosing information when it is } \\
\text { not mandatorily required }\end{array}$ & 1 & 2 & 3 & 4 & 5 \\
\hline OP6 & $\begin{array}{l}\text { Procedures does not matter when } \\
\text { managers it comes to the information } \\
\text { needs of important stakeholders e.g. } \\
\text { investors }\end{array}$ & 1 & 2 & 3 & 4 & 5 \\
\hline
\end{tabular}




\section{Appendix 3. Structural model for ritualism and opportunism}

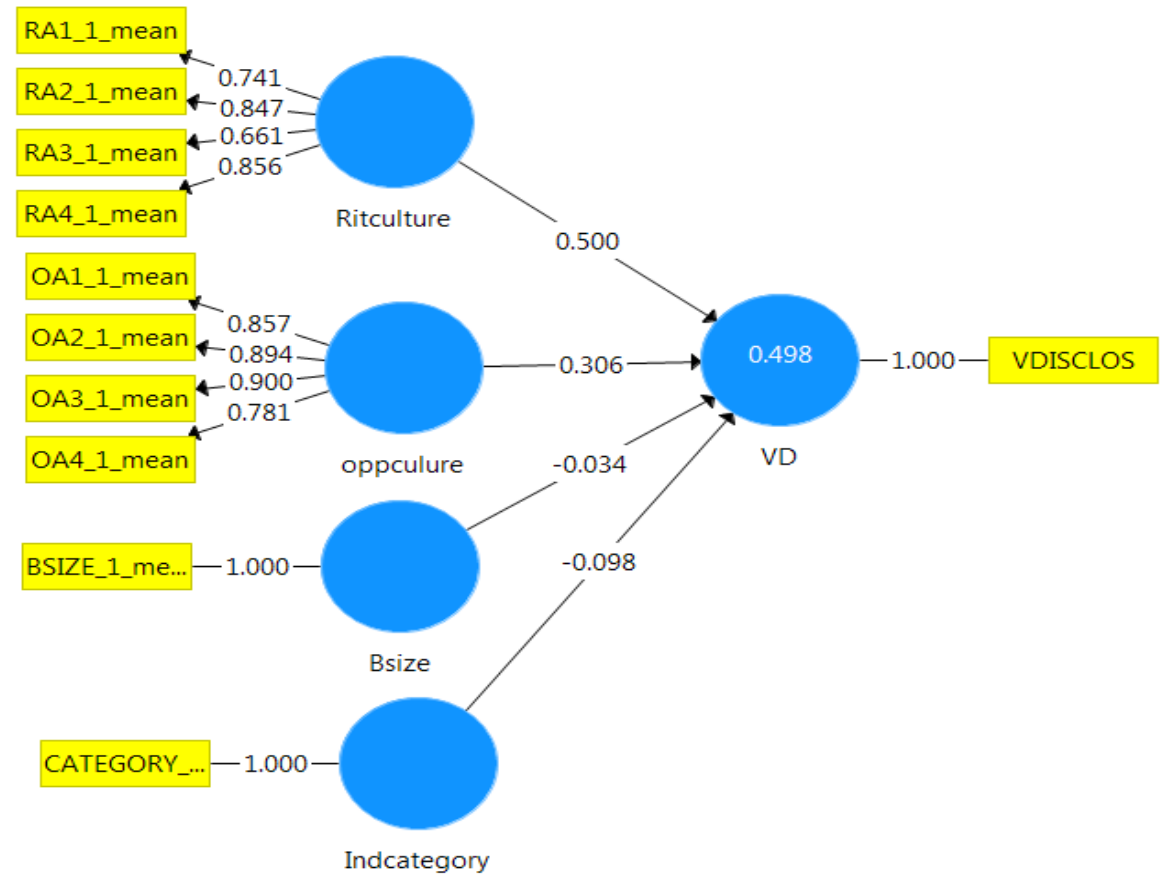

\section{Copyrights}

Copyright for this article is retained by the author(s), with first publication rights granted to the journal.

This is an open-access article distributed under the terms and conditions of the Creative Commons Attribution license (http://creativecommons.org/licenses/by/4.0/). 